\title{
Performance of the freshwater shrimp Atyaephyra desmarestii as indicator of stress imposed by textile effluents
}

\author{
Susana Casimiro and Maria Leonor Fidalgo
}

Casimiro, S. and Fidalgo, M. L. 2007. Performance of the freshwater shrimp Atyaephyra desmarestii as indicator of stress imposed by textile effluents. - Web Ecol. 7: 35-39.

\begin{abstract}
Textile plants consume large volumes of water and produce a great amount of wastewaters, which can be important sources of toxic discharges in receiving environments. The objective of this study was to evaluate the acute toxicity of textile effluents on the freshwater shrimp $A$. desmarestii. A whole effluent toxicity test procedure was used to determine the aggregate toxicity of three samples taken before and after wastewater treatment in a textile mill. The following $\mathrm{LC}_{50}-48 \mathrm{~h}$ values $(\%, \mathrm{v} / \mathrm{v})$ were calculated: Untreated effluent - 29\% effluent (sample 1), 22\% effluent (sample 2), and 47\% (sample 3); Treated effluent $-73 \%$ effluent (sample 1), 74\% effluent (sample 2), and > 100\% (sample 3). Based upon acute toxicity units $\left(\mathrm{TU}_{\mathrm{a}}=100 / \mathrm{LC}_{50}\right)$, untreated effluent varied from toxic in samples 1 and $3\left(2.00 \leq \mathrm{TU}_{\mathrm{a}} \leq 4.00\right)$ to very toxic in sample $2\left(\mathrm{TU}_{\mathrm{a}}>4.0\right)$, whereas treated effluent varied from no toxic in sample 3 to moderately toxic in samples 1 and $2\left(1.33 \leq \mathrm{TU}_{\mathrm{a}} \leq 1.99\right)$. Despite some limitations and constraints related to innate variability of industrial effluents, our results suggested that $A$. desmarestii can be a promising and potential test organism for assessing toxicity of complex chemical mixtures.
\end{abstract}

Susana Casimiro, Center of Marine and Environmental Research (CIIMAR), Rua dos Bragas, 289, PO-4050-123 Porto, Portugal. - M. L. Fidalgo (lfidalgo@fc.up.pt), CIIMAR and Dept of Zoology and Anthropology, Univ. OfOporto, Praça Gomes Teixeira, PO-4099002 Porto, Portugal.

Textile plants are important sources of toxic discharges in the receiving ecosystems. Their effluents may contain organic and inorganic substances that are potentially toxic to aquatic biota, and their identification involves expensive and complex analytical techniques (Gómez et al. 2001). In complex effluents, like those of textile industry, interactions among several pollutants might be synergistic, antagonistic, or simply additive. Consequently, complex mixtures can be considered as non-toxic when some substances are investigated individually but toxic when those mixtures are analysed. Many toxicological investigations involve the study of a single pollutant, which may give a clearer picture of toxicological effects than studies of complex chemical matrix such as textile effluents. However, in natural ecosystems, the biota is usually exposed to a com- plex and unknown combination of several pollutants (Abel 1998). Therefore, whole effluent toxicity (WET) tests can be more realistic than the study of individual pollutants (Juvonen et al. 2000, Mitchell et al. 2002, Araújo et al. 2005) and are recognized as practical and effective tools for the assessment of combined effects of toxic substances on aquatic ecosystems (Gómez et al. 2001). Though WET tests do not provide indication of the specific cause(s) of toxicity, they can contribute to address the overall effects that a mixture of pollutants might produce on the aquatic environment (EPA 2000, Nieto 2000, Rodriguez et al. 2006). In addition, despite some difficulties related to the interpretation of the results, WET tests can also contribute to protect aquatic biota from potentially detrimental effects imposed by effluent discharges. 
The freshwater shrimp Atyaephyra desmarestii was chosen as test organism because it is frequent in many Portuguese watercourses, including rivers, temporary streams, reservoirs, rice fields, and coastal lagoons (Fidalgo and Gerhardt 2003). Moreover, $A$. desmarestii represents an important link in the aquatic food webs (Descouturelle 1980, Fidalgo 1985) and its sensitivity to toxicants still has to be established. To our knowledge, apart from the studies by Abdennour et al. (2000) and Gerhardt et al. (2004), no toxicological studies have been conducted with $A$. desmarestii, what increases its use as a test organism. The use of local species adds the challenge of variability of a wild population, but results of toxicity tests provide a higher ecological relevance than the use of standard toxicity test species from laboratory cultures.

The objective of this study was to evaluate the acute toxicity of textile effluents on $A$. desmarestii. A WET test procedure was used to determine the aggregate toxicity of three different grab samples taken before and after wastewater treatment in a textile mill located in Northern Portugal.

\section{Material and methods}

The shrimps were exposed to various concentrations of the two tested effluents and mortality was used as a toxicological endpoint. The shrimps were collected from an area located upstream the reservoir of Crestuma-Lever $\left(41^{\circ} 4^{\prime} 24^{\prime \prime} \mathrm{N}, 8^{\circ} 29^{\prime} 18^{\prime \prime} \mathrm{W}\right)$, which is ca $20 \mathrm{Km}$ distance from the mouth of the Douro river, NW coast of Portugal. Animals were transported to the laboratory and acclimated during $7 \mathrm{~d}$ at least. We used an aerated aquaria supplied with unfiltered water from the shrimp sampling site (oxygen $=9.8 \pm 2.2 \mathrm{mg} \mathrm{O}_{2} 1^{-1} ; \mathrm{pH}=7.7 \pm 0.1$; conductivity = $268.3 \pm 38.6 \mu \mathrm{S} \mathrm{cm}^{-1}$; ammonia $=0.05 \pm 0.05 \mathrm{mg} \mathrm{N}-\mathrm{NH}_{4}$ $\mathrm{l}^{-1}$; total phosphorus $=0.6 \pm 0.2 \mathrm{mg} \mathrm{P}_{2} \mathrm{O}_{5} \mathrm{l}^{-1} ; \mathrm{BOD}_{5}=1.5 \pm$ $0.5 \mathrm{mg} \mathrm{O} \mathrm{l}^{-1}$; $\mathrm{COD}=5.7 \pm 2.3 \mathrm{mg} \mathrm{O}_{2} \mathrm{l}^{-1}$; planktonic chlorophyll $\underline{\mathrm{a}}=8.1 \pm 4.9 \mu \mathrm{g} \mathrm{l}^{-1}$ ). During the acclimation period, animals were kept at controlled conditions (temperature: $20 \pm 1^{\circ} \mathrm{C}$; photoperiod: $12 \mathrm{~h} \mathrm{light} / 12 \mathrm{~h}$ dark) and fed twice a day with tetramin and mud from the shrimp sampling site.

Tested effluents were collected from the homogenization tank (untreated effluent) and the final storage tank (treated effluent) of the wastewater treatment plant of the textile factory on three different dates: sample 1 (12 May 2005), sample 2 (16 June 2005), and sample 3 (4 October 2005). Polyethylene containers previously rinsed with effluent at the collection site were used for taking the samples. The samples were then transported in ice containers to the laboratory and stored in dark at $4^{\circ} \mathrm{C}$ until processing. Physical and chemical analyses of effluent samples included the in situ measurement of water temperature, dissolved oxygen, $\mathrm{pH}$, and conductivity by means of a Pocket Meter Multiline P4 (WTW, Germany). Determinations of biological oxygen demand $\left(\mathrm{BOD}_{5}\right)$ and chemical oxy- gen demand $(\mathrm{COD})$ were performed in the laboratory according to APHA (1992).

Acute toxicity bioassays were performed in static conditions, i.e. test organisms and tested solutions were placed in the experimental aquaria and kept there during the test without water renewal (APHA 1992, NIWA 1998). The exposures were carried out in 21 experimental aquaria containing $1.5 \mathrm{l}$ of different concentrations of tested effluents. Unfiltered water from the shrimp sampling site was used as negative control as well as for preparation of dilutions. Triplicate bioassays were done for each treatment, with eight animals per replicate (total body length $=19.1 \pm 2.4$ $\mathrm{mm}$ ). Following exploratory tests to determine approximate concentration range to be included in definitive tests, the shrimps were exposed for $48 \mathrm{~h}$ to five concentrations of untreated effluent $(6.25-50 \%, \mathrm{v} / \mathrm{v})$ and treated effluent $(12.5-100 \%, v / v)$. During the tests, aeration was not provided, the animals were not fed, and dead animals were daily counted and removed. Temperature, $\mathrm{pH}$, oxygen, and conductivity were monitored daily. Bioassays were only considered valid when the survival number of individuals in controls was higher than 90\% (EPA 2002).

The concentration which is lethal to $50 \%$ of the test organisms in the time period prescribed by the test $\left(\mathrm{LC}_{50}-\right.$ $48 \mathrm{~h}$ values \pm confidence limits) were determined using the Trimmed Spearman-Karber method developed by Hamilton (Software program version 1.5) (EPA 2002). Toxicity of samples was also expressed as acute toxicity units $\left(\mathrm{TU}_{\mathrm{a}}=100 / \mathrm{LC}_{50}\right)$, which correspond to the reciprocal of the effluent dilution that causes an acute effect by the end of the acute exposure period (CETESB 1987).

\section{Results}

The results of the chemical analyses of tested effluents are given in Table 1. A clear improvement of wastewater quality was recorded in the final storage tank as compared to the homogenization tank as a result of the high efficiency of wastewater treatment $\left(\mathrm{COD} \approx 87 \%, \mathrm{BOD}_{5}>92 \%\right.$, $\mathrm{TSS} \approx 59 \%$ ). The samples of treated effluent met the permitted limits established by Portuguese regulations relative to textile effluents released into the freshwater environment (published in D.L. no. 423 of 25 June 1997: pH 5.5-9.0, $\mathrm{BOD}_{5} 100 \mathrm{mg} \mathrm{O}_{2} \mathrm{l}^{-1}$, COD $250 \mathrm{mg} \mathrm{O}_{2} \mathrm{l}^{-1}$, colour not visible at 1:40 dilution). Treated effluent was also in compliance with some emission limits established in Portuguese regulations concerning general wastewater discharges published in D.L. no. 236 of 1 August 1998: $\mathrm{pH}$ 6.0-9.0, $\mathrm{BOD}_{5} 40 \mathrm{mg} \mathrm{O}_{2} \mathrm{l}^{-1}$, COD $150 \mathrm{mg} \mathrm{O}_{2} \mathrm{l}^{-1}$, TSS 60 $\mathrm{mg} \mathrm{l}^{-1}$.

The results of water chemistry variables monitored in experimental aquaria during the exposure period are presented in Table 2. Concerning untreated effluent, mean values of $\mathrm{pH}$ were slightly alkaline with a minimum of 7.4 and a maximum of 7.9. In treated effluent samples, $\mathrm{pH}$ 
Table 1. Basic characteristics of tested effluents (TSS - Total Suspended Solids; COD - Chemical Oxygen Demand; BOD $_{5}-$ Biochemical Oxygen Demand).

\begin{tabular}{|c|c|c|c|}
\hline Parameter & Unit & $\begin{array}{l}\text { Untreated Effluent } \\
\quad \text { Mean } \pm S D\end{array}$ & $\begin{array}{l}\text { Treated Effluent } \\
\text { Mean } \pm S D\end{array}$ \\
\hline Temperature & ${ }^{\circ} \mathrm{C}$ & $20.2 \pm 2.3$ & $19.2 \pm 4.6$ \\
\hline $\mathrm{pH}\left(25^{\circ} \mathrm{C}\right)$ & - & $7.5 \pm 0.7$ & $7.3 \pm 0.4$ \\
\hline Conductivity & $\mu S \mathrm{~cm}^{-1}$ & $649 \pm 235$ & $1162 \pm 139$ \\
\hline Dissolved $\mathrm{O}_{2}$ & $\mathrm{mg} \mathrm{O}_{2} 1^{-1}$ & $2.62 \pm 2.43$ & $6.54 \pm 2.93$ \\
\hline TSS & $\mathrm{mg} \mathrm{l}^{-1}$ & $295 \pm 461$ & $12 \pm 4$ \\
\hline COD & $\mathrm{mg} \mathrm{O}_{2} 1^{-1}$ & $525 \pm 314$ & $68 \pm 28$ \\
\hline $\mathrm{BOD}_{5}$ & $\mathrm{mg} \mathrm{O}_{2} \mathrm{l}^{-1}$ & $183 \pm 140$ & $<15$ \\
\hline Colour & $\mathrm{mg} \mathrm{l}^{-1}$ & $3352 \pm 2653$ & Non visible $1: 27$ \\
\hline & $\mathrm{Pt} /$ Co scale & & dilution $\pm 1: 79$ \\
\hline Detergents & $\begin{array}{l}\mathrm{mg} \mathrm{l}^{-1} \text { lauril } \\
\text { sulphate and } \\
\text { sodium }\end{array}$ & $45 \pm 17$ & $0.20 \pm 0.18$ \\
\hline
\end{tabular}

values ranged between 7.4 and 8.1. The average values of the treated effluent for conductivity were always higher than those of the untreated effluent. The average values of dissolved oxygen were quite variable during exposure time. This parameter reached the minimum average value of 4.4 $\mathrm{mg} \mathrm{l}^{-1}$ (untreated effluent sample 2 - very toxic) and the maximum value of $8.8 \mathrm{mg} \mathrm{l}^{-1}$ (treated effluent sample 3 non-toxic).
The results of acute toxicity bioassays performed are presented in Table 3. Values of $\mathrm{LC}_{50}-48 \mathrm{~h}$ corresponding to untreated effluent reached $29 \%$ effluent (sample 1), $22 \%$ effluent (sample 2), and $47 \%$ (sample 3). The following results were obtained for the treated effluent: $73 \%$ effluent (sample 1), $74 \%$ effluent (sample 2), and $>100 \%$ (sample 3).

Table 2. Water variables determined during the exposure period.

\begin{tabular}{|c|c|c|c|c|c|c|}
\hline $\begin{array}{l}\text { Effluent } \\
\text { sample }\end{array}$ & Sample & $\begin{array}{l}\mathrm{LC}_{50} \\
\text { Test } \\
\text { (h) }\end{array}$ & $\begin{array}{c}\mathrm{pH} \\
\text { mean } \pm S D\end{array}$ & $\begin{array}{c}\text { Temperature } \\
\left({ }^{\circ} \mathrm{C}\right) \\
\text { mean } \pm \mathrm{SD}\end{array}$ & $\begin{array}{c}\text { Dissolved } \\
\text { Oxygen } \\
\left(\mathrm{mg} \mathrm{O}_{2} \mathrm{l}^{-1}\right) \\
\text { mean } \pm \mathrm{SD}\end{array}$ & $\begin{array}{l}\text { Conductivity } \\
\left(\mu S \mathrm{~cm}^{-1}\right) \\
\text { mean } \pm \mathrm{SD}\end{array}$ \\
\hline Untreated & 1 & $\begin{array}{c}0 \\
24 \\
48\end{array}$ & $\begin{array}{l}7.39 \pm 0.12 \\
7.56 \pm 0.15 \\
7.64 \pm 0.23\end{array}$ & $\begin{array}{l}20.7 \pm 0.8 \\
21.9 \pm 0.9 \\
22.0 \pm 0.5\end{array}$ & $\begin{array}{l}7.13 \pm 1.12 \\
5.10 \pm 1.65 \\
6.99 \pm 0.61\end{array}$ & $\begin{array}{c}294.5 \pm 9.9 \\
298.5 \pm 9.7 \\
306.2 \pm 11.4\end{array}$ \\
\hline & 2 & $\begin{array}{c}0 \\
24 \\
48\end{array}$ & $\begin{array}{l}7.77 \pm 0.17 \\
7.49 \pm 0.12 \\
7.70 \pm 0.18\end{array}$ & $\begin{array}{l}24.6 \pm 0.3 \\
25.9 \pm 0.6 \\
25.5 \pm 0.1\end{array}$ & $\begin{array}{l}8.62 \pm 1.55 \\
4.41 \pm 1.33 \\
5.04 \pm 0.80\end{array}$ & $\begin{array}{l}429.5 \pm 89.7 \\
439.5 \pm 93.7 \\
452.3 \pm 92.5\end{array}$ \\
\hline & 3 & $\begin{array}{c}0 \\
24 \\
48\end{array}$ & $\begin{array}{l}7.51 \pm 0.12 \\
7.80 \pm 0.20 \\
7.91 \pm 0.17\end{array}$ & $\begin{array}{l}17.3 \pm 1.2 \\
22.8 \pm 0.2 \\
22.7 \pm 0.1\end{array}$ & $\begin{array}{l}6.71 \pm 1.20 \\
6.55 \pm 1.31 \\
7.27 \pm 0.76\end{array}$ & $\begin{array}{l}358.0 \pm 31.4 \\
368.3 \pm 34.1 \\
379.0 \pm 37.1\end{array}$ \\
\hline Treated & 1 & $\begin{array}{c}0 \\
24 \\
48\end{array}$ & $\begin{array}{l}7.45 \pm 0.12 \\
7.79 \pm 0.05 \\
7.87 \pm 0.07\end{array}$ & $\begin{array}{l}21.5 \pm 0.2 \\
22.5 \pm 0.1 \\
22.2 \pm 0.1\end{array}$ & $\begin{array}{l}8.34 \pm 0.70 \\
6.92 \pm 0.59 \\
7.37 \pm 0.76\end{array}$ & $\begin{array}{l}640.5 \pm 320.1 \\
649.3 \pm 325.5 \\
658.8 \pm 330.8\end{array}$ \\
\hline & 2 & $\begin{array}{c}0 \\
24 \\
48\end{array}$ & $\begin{array}{l}7.99 \pm 0.06 \\
8.10 \pm 0.18 \\
7.99 \pm 0.09\end{array}$ & $\begin{array}{l}18.1 \pm 0.1 \\
26.2 \pm 0.1 \\
25.3 \pm 0.3\end{array}$ & $\begin{array}{l}7.23 \pm 3.66 \\
5.41 \pm 1.06 \\
5.38 \pm 1.01\end{array}$ & $\begin{array}{l}600.7 \pm 272.0 \\
602.0 \pm 267.9 \\
602.2 \pm 258.7\end{array}$ \\
\hline & 3 & $\begin{array}{c}0 \\
24 \\
48\end{array}$ & $\begin{array}{l}7.23 \pm 0.20 \\
8.12 \pm 0.15 \\
8.09 \pm 0.04\end{array}$ & $\begin{array}{l}18.2 \pm 2.2 \\
22.9 \pm 0.1 \\
22.7 \pm 0.1\end{array}$ & $\begin{array}{l}8.78 \pm 0.24 \\
7.81 \pm 0.39 \\
8.02 \pm 0.59\end{array}$ & $\begin{array}{l}724.0 \pm 367.7 \\
736.5 \pm 372.7 \\
752.2 \pm 374.9\end{array}$ \\
\hline
\end{tabular}


Table 3. Results of acute toxicity tests for untreated and treated textile effluents expressed as $\mathrm{LC}_{50}-48 \mathrm{~h}(\%$, v/v) and acute toxicity units $\left(\mathrm{TU}_{\mathrm{a}}\right)$.

\begin{tabular}{|c|c|c|c|c|}
\hline $\begin{array}{l}\text { Effluent } \\
\text { sample }\end{array}$ & $\begin{array}{l}\text { Sample } \\
\text { number }\end{array}$ & $\begin{array}{c}\mathrm{LC}_{50}-48 \mathrm{~h} \\
\text { (95\% confidence } \\
\text { interval) }\end{array}$ & $\begin{array}{l}\text { Acute toxic units } \\
\left(\mathrm{TU}_{\mathrm{a}}=100 / \mathrm{LC}_{50}\right)\end{array}$ & $\begin{array}{c}\text { Effluent } \\
\text { Classification } \\
\text { (CETESB } \\
1987)\end{array}$ \\
\hline \multirow[t]{3}{*}{ Untreated } & 1 & $29 \%(26-32)$ & 3.45 & Toxic \\
\hline & 2 & $22 \%(20-25)$ & 4.55 & Very toxic \\
\hline & 3 & $47 \%(40-54)$ & 2.13 & Toxic \\
\hline \multirow[t]{3}{*}{ Treated } & 1 & $73 \%(30-180)$ & 1.37 & $\begin{array}{l}\text { Moderately } \\
\text { toxic }\end{array}$ \\
\hline & 2 & $74 \%(68-81)$ & 1.35 & $\begin{array}{l}\text { Moderately } \\
\text { toxic }\end{array}$ \\
\hline & 3 & $>100 \%$ & - & Non-toxic \\
\hline
\end{tabular}

\section{Discussion}

According to the classification adopted by CETESB (1987) for the characterization of toxicity samples, untreated effluent varied from toxic in samples 1 and $3(2.00$ $\left.\leq \mathrm{TU}_{\mathrm{a}} \leq 4.00\right)$ to very toxic in sample $2\left(\mathrm{TU}_{\mathrm{a}}>4.0\right)$. In turn, treated effluent varied from non-toxic in sample 3 to moderately toxic in samples 1 and $2\left(1.33 \leq \mathrm{TU}_{\mathrm{a}} \leq 1.99\right)$. In other words, results of acute toxicity bioassays changed from date to date. This variability might reflect probable variations of pollution load as a function of the quantity and quality of processed products in the textile mill. In fact, the constituents and the concentrations might vary with the hour of the day, the day of the week, the month of the year, and other conditions such as fashion pressure.

We point out that the effluent quality of treated effluent is not violating the Portuguese discharge limits, but could show toxicity as revealed by acute toxicity bioassays on two sampling dates. The lack of correspondence between the information given by $\mathrm{LC}_{50}$ values and basic characteristics of treated effluent shows that Portuguese regulations based upon a set of frequently used chemical variables $(\mathrm{pH}$, $\mathrm{BOD}_{5}, \mathrm{COD}$, and colour) is not enough to evaluate the potential harmful effects of textile discharges on the aquatic biota. For this reason, the existing receiving water discharge standards should be reviewed to include chemical monitoring of potential contaminants jointly with toxicity tests. This would be in agreement with several authors (Villegas-Navarro et al. 1999, Sponza 2002 a, b, 2006, Rodriguez et al. 2006) who emphasized the need of using a comprehensive approach by including bioassays for effluent monitoring in view of a more complete toxicological risk evaluation. Sponza (2006), in a study conducted to evaluate the toxicity of effluents of the treatment plants of the chemical dye production industry in Turkey, advocated the incorporation of toxicity tests into receiving water dis- charge standards in order to preserve receiving ecosystems. Similarly, Rodriguez et al. (2006), based upon their study carried in the Basque country, recommended the incorporation of biocriteria derived from WET tests in European water regulations as a contribution to the maintenance of the good ecological status of receiving rivers.

Testing effluents from the same textile plant that we studied, Andrade (2004) mentioned that treated effluent was not lethal to the adults of zebra fish Danio rerio $\left(\mathrm{LC}_{50}\right.$ $>100 \%$ ), whereas $D$. rerio larvae showed several malformations when exposed to the same effluent. Therefore, based on our results and on those of Andrade (2004), we assume that $A$. desmarestii might be more sensitive than $D$. rerio adults. A. desmarestii was recently used for toxicological assessment of an acid mine drainage in Portugal based on behaviour and survival. In this study, Gerhardt et al. (2004) reported that $A$. desmarestii was more sensitive to acid mine drainage than the mosquito fish Gambusia holbrooki. Nevertheless, to evaluate $A$. desmarestii sensitivity, some reference toxicants such as potassium dichromate should be tested in future studies. Furthermore, the assessment of toxic effects resulting from textile discharges should include a multispecies toxicity test that include organisms belonging to different trophic levels to maintain the good ecological status of receiving ecosystems. In conclusion, $A$. desmarestii can be considered a promising and potential test organism to evaluate toxicity of complex chemical mixtures, because it is ecologically more relevant to predict the potential effects of contaminants based on native species instead of using only standard toxicity test species from laboratory cultures.

Acknowledgements - We thank Dr Anabela Viana for allowing us to take effluent samples. We also acknowledge the comments of the anonymous referees who helped us improve the manuscript. 


\section{References}

Abdennour, C. et al. 2000. Trace metals in marine, brackish and freshwater prawns (CRUSTACEA, Decapoda) from northeast Algeria. - Hydrobiologia 432: 217-227.

Abel, P. D. 1998. Water Pollution Biology. - Taylor and Francis.

Andrade, R. M. 2004. Efeitos da exposição de peixe zebra, Danio rerio, a um efluente têxtil. Dissertação de Mestrado em Ecologia Aplicada. - Faculdade de Ciências da Universidade do Porto.

APHA. 1992. Standard methods for the examination of water and wastewater $\left(18^{\text {th }}\right.$ ed.). - American Public Health Association.

Araújo, C. V. M. et al. 2005. The use of Microtox ${ }^{\circledR}$ to assess toxicity removal of industrial effluents from the industrial district of Camaçari (BA, Brazil). - Chemosphere 58: 12771281.

CETESB 1987. Toxicidade Aguda de Efluentes das Indústrias da Bacia do rio Paraiba do sul no Estado de São Paulo, Brasil. Companhia de Tecnologia de Saneamento Ambiental.

D. L. n. 423 of 25 June 1997. Ministries of Economy, Health and Environment. - Diário da República I Série B: 3111-3112.

D. L. n. 236 of 1 August 1998. Ministries of Economy, Health and Environment. - Diário da República I Série A: 3676-3721.

Descouturelle, G. 1980. Contribution à l'étude du contrôle de l'évolution sexuelle, de la croissance, de la mue et de leurs interactions chez la crevette d'eau douce Atyaephyra desmaresti. Thèse pour obtenir le grade de Docteur d'État. - Université de Nancy.

EPA. 2000. Method Guidance and Recommendations for Whole Effluent Toxicity (WET) Testing (40 CFR Part 136). - Environmental Protection Agency.

EPA. 2002. Methods for measuring the acute toxicity of effluents and receiving waters to freshwater and marine organisms. Environmental Protection Agency.

Fidalgo, M. L. 1985. Contribuição para o conhecimento da biologia de Atyaephyra desmaresti. Alguns aspectos de dinâmica populacional e do balanço energético. Dissertação de Doutoramento em Biologia. - Faculdade de Ciências da Universidade do Porto.
Fidalgo, M. L. and Gerhardt, A. 2003. Distribution of the freshwater shrimp, Atyaephyra desmarestii in Portugal (Decapoda, Natantia). - Crustaceana 75: 1375-1385.

Gerhardt, A. et al. 2004. Macroinvertebrate response to acid mine drainage: community metrics and on-line behavioural toxicity bioassay. - Environ. Pollut. 130: 263-274.

Gómez, C. E. et al. 2001. Toxicity tests to assess pollutants removal during wastewater treatment and the quality of receiving waters in Argentina. - Environ. Toxicol. 16: 217224.

Juvonen, R. et al. 2000. A Battery of Toxicity Tests as Indicators of Decontamination in Composting Oily Waste. - Ecotox. Environ. Safe. 47: 156-166.

Mitchell, J. A. K. et al. 2002. Developments in ecotoxicity testing. - Rev. Environ. Sci. Biotechnol. 1: 169-198.

Nieto, R. 2000. Caracterização Ecotoxicológica de Efluentes Líquidos Industriais - Ferramenta para ações de controle da poluição da águas. - In: Congresso Interamericano de Engenharia Sanitária e Ambiental 27, 2000. Porto Alegre, Anais, 3-8 Dez, pp. 1-17.

NIWA. 1998. Standard Methods for Whole Effluent Toxicity Testing: Development and Application. NIWA Client Report: MfE80205. National Institute of Water and Atmospheric Research. Hamilton, N. Z, November 1998.

Rodriguez, P. et al. 2006. Ecotoxicological assessment of effluents in the Basque country (Northern Spain) by acute and chronic toxicity tests using Daphnia magna Straus. - Ecotoxicology 15: 559-572.

Sponza, D. T. 2002a. Incorporation of toxicity tests into the Turkish industrial discharge monitoring systems. - Arch. Environ. Contam. Toxicol. 43: 186-197.

Sponza, D. T. 2002b. Necessity of toxicity assessment in Turkish industrial discharges (examples from metal and textile industry effluents). - Environ. Monit. Asses. 73: 41-66.

Sponza, D. T. 2006. Toxicity studies in a chemical dye production industry in Turkey. - J. Hazard. Mater. A138: 438447.

Villegas-Navarro, A. et al. 1999. Evaluation of Daphnia magna as an indicator of toxicity and treatment efficacy of textile wastewaters. - Environ. Int. 25: 619-624. 